\title{
VJEŠTAČENJE U UPRAVNOM SPORU
}

\author{
Željka Zrilić Ježek, dipl. iur.*
}

\author{
UDK: $340.66: 342.9$ \\ https://doi.org/10.30925/zpfsr.40.1.23 \\ Ur.: 24. prosinca 2018. \\ Pr.: 29. siječnja 2019. \\ Stručni rad
}

\begin{abstract}
Sažetak
Cilj je obrade ove teme dati pregled postupka vještačenja u upravnom sporu, prikazati pravila po kojima se provodi, ali i ukazati na specifičnosti u odnosu na parnični postupak. Naznačeni su neki aspekti vještačenja, odnos prema provedenom vještačenju u upravnom postupku, određivanje zadatka vještaku sukladno mjerodavnom materijalnom propisu koji regulira određeno upravno područje te ocjena danih nalaza i mišljenja sudskih vještaka. Svrha je rada pružiti odgovore ili barem dati naznake rješenja spornih situacija koje se javljaju u postupcima vještačenja, uz prikaz relevantne sudske prakse.
\end{abstract}

Ključne riječi: vještak; vještačenje; nalaz i mišljenje vještaka; upravni spor.

\section{UVOD}

Provođenje vještačenja u upravnom sporu ponekad je, ovisno o predmetu upravne stvari, jedino učinkovito dokazno sredstvo koje stoji na raspolaganju tužitelju pri osporavanju zakonitosti upravnog akta.

Ustavom Republike Hrvatske zajamčena je sudska kontrola zakonitosti pojedinačnih akata upravnih vlasti i tijela koja imaju javne ovlasti, ${ }^{1}$ stoga se u duhu ustavnog i konvencijskog prava na pravično suđenje i primjene načela jednakosti oružja u upravnom sporu provodi neovisno, stručno, sudsko vještačenje kada stranka osporava odlučne činjenice, osobito ako su one utvrđene vještačenjima po ovlaštenim vještacima javnopravnih tijela provedenim u upravnom postupku.

Radi ispunjavanja uvjeta postavljenih odredbom članka 6. Konvencije za zaštitu ljudskih prava i temeljnih sloboda Vijeća Europe ${ }^{2}$ u upravnom sporu propisano je

* Željka Zrilić Ježek, dipl. iur., sutkinja, Upravni sud u Zagrebu; zeljka.zrilicjezek@uszg. pravosudje.hr.

1 Članak 19. stavak 2. Ustava Republike Hrvatske (Narodne novine, br. 56/90., 135/97., 8/98., 113/00., 124/00., 28/01., 41/01., 76/10., 85/10., 5/14.)

2 Narodne novine - Međunarodni ugovori, br. 18/97., 6/99., 14/02., 13/03., 9/05., 1/06., 2/10. - u daljnjem tekstu: Konvencija.

Članak 6.1. glasi: „Radi utvrđivanja svojih prava i obveza građanske naravi ili u slučaju podizanja optužnice za kazneno djelo protiv njega svatko ima pravo da zakonom ustanovljeni neovisni i nepristrani sud pravično, javno i u razumnom roku ispita njegov slučaj. Presuda se mora izreći javno, ali se sredstva priopćavanja i javnost mogu isključiti iz cijele rasprave ili 
da sud odlučuje na temelju usmene, neposredne i javne rasprave ${ }^{3}$ na kojoj stranke imaju mogućnost raspraviti sva sporna pitanja te utvrditi činjenice i izvoditi dokaze. Koje je činjenice potrebno utvrditi određuje materijalni propis koje se primjenjuje u konkretnoj upravnoj stvari, o čemu, u konačnici, ovisi i kojim će se dokaznim sredstvima te pravno-relevantne činjenice i utvrđivati. U ne malom broju slučajeva stranke (uglavnom tužitelji) su iznenađene učestalim odbijanjem dokaznih prijedloga od strane suda, zaboravljajući da upravnom sporu prethodi provedeni upravni postupak, u pravilu u dva stupnja, u kojem se izvode dokazi, kao i zbog činjenice da se predlaže široka paleta dokaznih sredstava koja nije primjerena konkretnoj upravnoj stvari. ${ }^{4}$

Sud u upravnom sporu izvodi dokaze prema pravilima kojima je uređeno dokazivanje u parničnom postupku $\mathrm{u}^{5}$ te su za postupak vještačenja mjerodavne odredbe članaka 250. do 263. Zakona o parničnom postupku, ${ }^{6}$ kao i odredbe članaka 125 . do 127. Zakona o sudovima. ${ }^{7}$

\section{VJEŠTACI}

Zakon o sudovima propisuje $\mathrm{e}^{8}$ da stalni sudski vještaci na temelju svoga stručnog znanja pružaju sudu uslugu davanja vještačkog nalaza i mišljenja (vještačenje) kada je to potrebno radi utvrđivanja ili razjašnjenja činjenica koje se utvrđuju u postupku.

Dakle, sudski vještaci su osobe koje imaju posebno stručno znanje kojim ne raspolaže sud, te davanjem nalaza i mišljenja (vještačenje) pomažu pri utvrđivanju ili razjašnjenju neke relevantne činjenice. Sudski vještak iznosi sudu svoje zapažanje o nekoj činjenici, uzročno-posljedičnom odnosu između nekih činjenica, iznosi svoja stručna stajališta te donosi zaključke o specifičnoj materiji koju sud ne poznaje. Ako se radi o utvrđivanju neke činjenice do koje se može doći, primjerice, jednostavnom računskom operacijom, ili pribavljanjem podataka iz službenih evidencija, ili drugim dokaznim sredstvima (saslušanjem stranke, svjedoka i sl.) nema mjesta provođenju

njezinog dijela zbog razloga koji su nužni u demokratskom društvu radi interesa morala, javnog reda ili državne sigurnosti, kad interesi maloljetnika ili privatnog života stranaka to traže, ili u opsegu koji je po mišljenju suda bezuvjetno potreban u posebnim okolnostima gdje bi javnost mogla biti štetna za interes pravde“.

3 Članak 7. stavak 1. Zakona o upravnim sporovima (Narodne novine, br. 20/10., 143/12., 152/14., 94/16., 29/17.) - načelo usmene rasprave. Sud može odlučiti u upravnom sporu bez održavanja rasprave samo u slučajevima propisanim ovim Zakonom (stavak 2.).

4 Primjerice, u predmetima priznavanja prava na invalidsku mirovinu, predlaže se saslušanje stranke i/ili svjedoka iako se činjenica invalidnosti može utvrditi jedino na temelju ocjene neovisne stručne osobe

5 Članak 33. stavak 5. Zakona o upravnim sporovima - ovim zakonom napuštena je odgovarajuća primjena Zakona o parničnom postupku koja je bila propisana odredbom članka 60. Zakona o upravnim sporovima (Narodne novine, br. 53/91., 9/92., 77/92.) te je odabrano taksativno propisivanje primjene pravila parničnog postupka.

6 Zakon o parničnom postupku, Narodne novine, br. 53/91., 91/92., 112/99., 129/00., 88/01., 117/03., 88/05., 2/07., 96/08., 84/08., 123/08., 57/11., 25/13., 89/14. - dalje u tekstu: ZPP.

7 Zakon o sudovima, Narodne novine, br. 28/13., 33/15., 82/15., 82/16. - dalje u tekstu: ZS.

8 Čl. 125. ZS. 
vještačenja, jer se u tom slučaju ne radi o potrebi poznavanja nekoga stručnog područja. Kriterij procjene stručnosti kojim sud ne raspolaže jest ona razina znanja koja nadilazi „stupanj znanja čovjeka koji posjeduje opće obrazovanje i životno iskustvo kao sudac". 9

Međutim, vještak nikada nije ovlašten davati svoj stav o primjeni pravne norme ili davati odgovore na pravna pitanja, niti mu to smije biti zadani zadatak jer je to $\mathrm{u}$ isključivoj nadležnosti suda, pozivom na staro rimsko pravilo iura novit curia, prema kojemu je sud dužan poznavati zakon te ga protumačiti i primijeniti. Ipak, ako se radi o utvrđivanju sadržaja stranog prava, dokazivanje je dopušteno, kao i kada pravna pravila sadržavaju i neka pravila iskustva ili standarde. ${ }^{10}$ Vještak može izložiti sudu stručne informacije o pravilima struke kada je to potrebno radi određivanja sadržaja (značenja) mjerodavne pravne norme, osobito onda kada se ona koristi nedefiniranim pojmovima kao što su pravni standardi. U tom slučaju radi se o vještačenju o pravilima struke u funkciji utvrđivanja sadržaja pravne norme. ${ }^{11}$

Prema odredbama Zakona o sudovima i Zakona o parničnom postupku ${ }^{12}$ sudsko vještačenje mogu obavljati fizičke osobe, koje imaju posebno stručno znanje iz određenog područja. Vještačenje se može povjeriti i pravnoj osobi, koja može obavljati sudsko vještačenje samo u okviru svoje registrirane djelatnosti i uz uvjet da to obavljaju njihovi zaposlenici koji su imenovani za stalnog sudskog vještaka, te ako za zaposlenike koji su imenovani stalnim sudskim vještacima imaju zaključen ugovor o osiguranju od odgovornosti za obavljanje poslova stalnoga sudskog vještaka.

Vještačenje se može povjeriti i stručnoj ustanovi (bolnici, kemijskom laboratoriju, fakultetu i sl.). Ako postoje posebne ustanove za određene vrste vještačenja (vještačenje lažnog novca, rukopisa, daktiloskopsko vještačenje i sl.), takva vještačenja, a osobito složenija, povjeravat će se, u prvom redu, tim ustanovama. ${ }^{13}$

\subsection{Imenovanje vještaka}

Za stalnoga sudskog vještaka može biti imenovana fizička osoba sa završenim odgovarajućim stručnim studijem, preddiplomskim ili diplomskim sveučilišnim studijem. Stalnim sudskim vještakom iznimno se može imenovati i fizička osoba sa završenom srednjom školskom spremom odgovarajuće struke. Za stalnoga sudskog vještaka može biti imenovan državljanin Republike Hrvatske, državljanin države članice Europske unije ili državljanin države potpisnice Sporazuma o Europskom gospodarskom prostoru. Nadalje, za imenovanje je potrebno nakon završenog odgovarajućeg studija odnosno odgovarajuće škole raditi propisani broj godina ${ }^{14}$

9 Poznić, B., i dr., Zakon o parničnom postupku s komentarom, Beograd, 1957., str. 220.

10 Triva, S., Dika, M., Građansko parnično procesno pravo, 7. izmijenjeno i dopunjeno izd., Zagreb, Narodne novine, 2004., str. 526.

11 Dika, M., Građansko parnično procesno pravo - Utvrđivanje činjenica, VII. knjiga, Zagreb, Narodne novine, 2018., str. 630.

12 Čl. 126. ZS/252. ZPP.

13 Čl. 252. st. 2. i 3. ZPP.

14 - najmanje 8 godina - ako je završila diplomski sveučilišni studij ili specijalistički diplomski stručni studij,

- najmanje 10 godina - ako je završila odgovarajući preddiplomski sveučilišni studij ili 
na poslovima u struci, uspješno završiti stručnu obuku i imati sklopljen ugovor o osiguranju od odgovornosti za obavljanje poslova stalnoga sudskog vještaka. Iznimno, liječnici specijalisti uvjet za obavljanje poslova stalnoga sudskog vještaka stječu nakon položenoga specijalističkog ispita i nisu dužni obaviti stručnu obuku.

Stalne sudske vještake imenuje i razrješava predsjednik županijskog ili trgovačkog suda za svoje područje. Stalni sudski vještaci imenuju se na vrijeme od četiri godine i mogu biti ponovno imenovani. Imenovani stalni sudski vještaci mogu pružati svoje usluge na području cijele Republike Hrvatske. Sudski vještaci smiju isticati zvanje sudskoga vještaka samo ako daju nalaz i mišljenje na zahtjev suda ili zahtjev stranaka radi ostvarenja njihovih prava, a u drugim slučajevima samo po odobrenju predsjednika suda koji ih je imenovao. ${ }^{15}$

Protiv odluke kojom se zahtjev za imenovanje sudskim vještakom odbija, podnositelj ima pravo žalbe Ministarstvu pravosuđa u roku od 15 dana od dostave odluke. Protiv rješenja Ministarstva pravosuđa žalba nije dopuštena, ali se može pokrenuti upravni spor pred nadležnim upravnim sudom.

Odluku o izboru osobe vještaka stranke često prepuštaju sudu, koji ih u tom slučaju odabire s jedinstvenog elektroničkog popisa kojeg vodi Ministarstvo pravosuđa, po pojedinim područjima vještačenja, i popisa pravnih osoba za obavljanje poslova sudskog vještačenja, za područje cijele Republike Hrvatske. ${ }^{16}$ Službenu listu stalnih sudskih vještaka treba shvatiti kao pomoćno sredstvo, podsjetnik, adresar osoba prikladnih za obavljanje vještačenja i ima značenje preporuke i sugestije, a ne i obvezatnog izvora. ${ }^{17}$

\subsection{Izuzeće vještaka}

Vještak može biti izuzet iz istih razloga iz kojih može biti izuzet sudac, ${ }^{18}$ ali

preddiplomski stručni studij,

- najmanje 12 godina - ako je završila odgovarajuću srednju školu, a za pojedinu struku nema odgovarajućeg preddiplomskog sveučilišnog studija ili preddiplomskog stručnog studija odnosno diplomskog sveučilišnog studija ili specijalističkog diplomskog stručnog studija.

15 Čl. 127. ZS.

16 Ažurirani popis sudskih vještaka nalazi se i na internet stranici Sudačke mreže, nevladine i neprofitne udruge, utemeljene 1999. godine, sa sjedištem u Zagrebu. Osnovali su je suci i pravni stručnjaci kao odgovor na zahtjev pravne profesije za učinkovitijim radom sudstva uz potporu moderne informatičke tehnologije, a u skladu sa zadanim smjernicama i preuzetim obvezama Vlade RH, po načelima Sporazuma o stabilizaciji i pridruživanju Republike Hrvatske EU.

17 Triva, S., Dika, M., op. cit., str. 530.

18 Razlozi za izuzeće suca propisani su odredbom članka 15. stavak 1. Zakona o upravnim sporovima:

„Sudac ne može odlučivati niti sudjelovati u sporu:

1. ako je sam stranka, zakonski zastupnik ili opunomoćenik stranke ili ako je sa strankom u odnosu suovlaštenika ili suobveznika,

2. ako mu je stranka ili zakonski zastupnik ili opunomoćenik stranke srodnik po krvi u pravoj liniji do bilo kojeg stupnja, a u pobočnoj do četvrtog stupnja, ili mu je bračni drug, izvanbračni drug ili srodnik po tazbini do drugog stupnja, bez obzira na to je li brak prestao ili nije,

3. ako je skrbnik, posvojitelj ili posvojenik stranke, njezina zakonskog zastupnika ili opunomoćenika, 
se za vještaka može uzeti i osoba koja je već bila saslušana kao svjedok. Stranka je dužna čim sazna da postoji razlog za izuzeće, a najkasnije prije početka izvođenja dokaza vještačenjem, podnijeti obrazloženi zahtjev za izuzeće vještaka u kojem će navesti okolnosti na kojima temelji svoj zahtjev. Ukoliko stranka sazna za razlog izuzeća poslije obavljenog vještačenja i prigovara vještačenju iz tog razloga, sud će postupiti kao da je zahtjev za izuzeće stavljen prije obavljenog vještačenja. Žalba nije dopuštena protiv rješenja suda kojim se zahtjev za izuzeće prihvaća, niti posebna žalba protiv rješenja kojim se zahtjev odbija.

\subsection{Dužnost vještačenja}

Određeni vještak dužan je odazvati se pozivu suda i iznijeti svoj nalaz i mišljenje. Okolnosti za oslobođenje od dužnosti vještačenja propisane su na isti način kao i razlozi zbog kojih bi svjedok mogao uskratiti svjedočenje ili odgovor na pojedino pitanje. ${ }^{19} \mathrm{Na}$ zahtjev vještaka, a iz opravdanih razloga, sud ga može osloboditi dužnosti vještačenja, primjerice ako je predmet vještačenja specifičan i zahtijeva posebnu stručnost u kojem slučaju može ujedno predložiti i vještaka koji se bavi tim posebnim područjem. Zakon o parničnom postupku ${ }^{20}$ ne propisuje poimence koji su to „drugi opravdani razlozi“ zbog kojih bi sud mogao osloboditi vještaka dužnosti vještačenja, no praksa je iskristalizirala razloge kao što su zauzetost, službena spriječenost, bolest, i sl.

Vještaci su dužni za sebe zadržati sve što su u obavljanju vještačenja doznali o strankama i njihovim pravima, obvezama i pravnim interesima te čuvati tajnost svih podataka koji tijekom sudskog postupka nisu bili predmet javne rasprave. Pod tajnom se posebno podrazumijeva sve ono što je kao tajna određeno zakonom ili drugim propisom, sve ono što je kao tajna određeno općim aktom pravne osobe, drugog tijela, organizacije ili institucije, podatci i isprave posebno označene kao tajna od strane državnog tijela ili pravne osobe, drugog tijela, organizacije ili institucije te podatci i isprave koje su predsjednik suda ili ovlašteni službenik suda označili kao tajne. ${ }^{21}$

4. ako je u istom predmetu sudjelovao u donošenju odluke u upravnom postupku ili prvostupanjskom upravnom sporu,

5. ako postoje druge okolnosti koje dovode u sumnju njegovu nepristranost“".

19 Članak 237. ZPP-a: „Svjedok može uskratiti svjedočenje o onome što mu je stranka kao svom punomoćniku povjerila; o onome o čemu se stranka ili druga osoba svjedoku kao vjerskom ispovjedniku ispovjedila; o činjenicama što ih je svjedok saznao kao odvjetnik, liječnik, ili u obavljanju kakva drugog poziva ili kakve druge djelatnosti ako postoji obveza da se kao tajna čuva ono što se saznalo u obavljanju tog poziva ili djelatnosti. članak 238. ZPP-a: Svjedok može uskratiti odgovor na pojedina pitanja ako za to postoje važni razlozi, a osobito ako bi svojim odgovorom na ta pitanja izložio teškoj sramoti, znatnoj imovinskoj šteti ili kaznenom gonjenju sebe ili svoje srodnike po krvi u pravoj liniji do bilo kojeg stupnja, a u pobočnoj liniji do trećeg stupnja zaključno, svoga bračnog druga ili srodnike po tazbini do drugog stupnja zaključno i onda kad je brak prestao te svog skrbnika ili štićenika, usvojitelja ili usvojenika.

Sudac pojedinac ili predsjednik vijeća upozorit će svjedoka (i vještaka) da može uskratiti davanje iskaza i odgovora na postavljeno pitanje“.

20 Čl. 253. st. 3. ZPP-a.

21 Čl. 130. ZS. 
Pravilnikom o stalnim sudskim vještacima ${ }^{22}$ propisani su uvjeti i postupak imenovanja stalnih sudskih vještaka, njihova prava i dužnosti te visina nagrade $i$ naknade troškova za njihov rad.

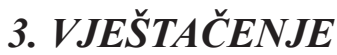

Zakonom o parničnom postupku propisano je da će sud izvesti dokaz vještačenjem kada je radi utvrđivanja ili razjašnjenja neke činjenice potrebno stručno znanje kojim sud ne raspolaže. ${ }^{23}$

Stalni sudski vještaci svojim stručnim znanjem pružaju sudu uslugu davanja vještačkog nalaza i mišljenja (vještačenje) kada je to potrebno radi utvrđivanja ili razjašnjenja činjenica koje se utvrđuju u postupku. ${ }^{24}$

Iz citiranih zakonskih odredbi Dika ${ }^{25}$ izvodi zaključak o dvije osnovne funkcije vještačenja: kao instrumenta za utvrđivanje činjenica kada je za to potrebno stručno znanje kojim sud ne raspolaže i kao instrumenta za razjašnjenje činjeničnog stanja. Bestvina i Balić2 ${ }^{6}$ također navode dvostruku funkciju vještaka, kao dokaznog sredstva kad svojom stručnošću obavještava sud o svojim zapažanjima, te kao stručnog pomagača u obavljanju funkcije suđenja pri utvrđivanju činjeničnog stanja, kad vještak svojom stručnošću pomaže sudu da formira svoje mišljenje o zapaženom.

Kod utvrđivanja činjenica sporno je postoji li pravno-relevantna činjenica, za koje utvrđenje sud nema potrebno stručno znanje, dok je kod razjašnjenja sudu potrebna pomoć vještaka u ocjeni te činjenice.

\subsection{Dokazni prijedlog}

Sud rukovodi postupkom vještačenja, ali nikada, bez prijedloga stranke, ovaj dokaz ne može provesti ex officio, prvenstveno jer vještak ima pravo na nagradu za obavljeno vještačenje, te pravo na naknadu putnih troškova i troškova za prehranu i prenoćište, na naknadu izmakle zarade i troškova vještačenja, ${ }^{27}$ a koji ne mogu ići na teret sredstava suda jer za tu namjenu nema predviđenih financijskih sredstava. Čak i ako sud usvoji prijedlog stranke i odredi vještačenje, isto se neće provesti ukoliko stranka u danom roku ne predujmi zatražena sredstva i položi ih na račun suda. Dakle, da bi se uopće proveo ovaj dokazni prijedlog stranke i provelo vještačenje, stranka je dužna prethodno predujmiti troškove te ako uspije u sporu i predmetna upravna stvar bude meritorno riješena, imat će pravo na povrat troška vještačenja. ${ }^{28}$

22 Narodne novine, br. 38/14., 123/15., 29/16.

23 Čl. 250. ZPP.

24 Čl. 125. ZS.

25 Dika, M., op. cit., str. 627.

26 Bestvina, M., Balić, Đ., Imenovanje sudskih vještaka i procjenitelja u RH i ostalim susjednim državama, Simpozij o izvlaštenju nekretnina, Zagreb, 13. listopada 2018., str. 4.

27 Čl. 256. st. 1. ZPP

28 Čl. 79. Zakona o upravnim sporovima propisuje naknadu troškova upravnog spora. Zaključkom o pravnom shvaćanju sa sjednice sudaca Visokog upravnog suda Republike Hrvatske od 12. veljače 2018. broj: 6 Su-85/2018-3 navedeno je da kada je presudom upravnog suda ili Visokog upravnog suda Republike Hrvatske poništeno rješenje javnopravnog tijela i predmet vraćen na 
Međutim, ako je stranka slabijeg imovnog stanja, te nije u mogućnosti predujmiti troškove predloženog vještačenja, dužna je postupiti sukladno posebnom propisu kojim se uređuje besplatna pravna pomoć i podnijeti zahtjev nadležnom uredu državne uprave u županiji, odnosno nadležnom upravnom tijelu Grada Zagreba za odobravanje sekundarne pravne pomoći. ${ }^{29}$ Besplatnom pravnom pomoći ostvaruje se jednakost svih pred zakonom, te se osigurava, u skladu s odredbama Zakona o besplatnoj pravnoj pomoći, djelotvorno ostvarenje pravne zaštite te pristupa sudu i drugim javnopravnim tijelima.

Upravo iz razloga što trošak vještačenja ne može ići na teret sredstava suda, $u$ određenoj mjeri ograničeno je inkvizitorno načelo, koje sudu daje pravo samostalno odlučiti koje će dokaze izvesti i koje činjenice uzeti utvrđenim..$^{30}$

Nastavno, stranke su obvezne u tužbi i odgovoru na tužbu iznijeti sve činjenice na kojima temelje svoje zahtjeve, predložiti dokaze potrebne za njihovo utvrđivanje i izjasniti se o činjeničnim navodima i dokaznim prijedlozima drugih stranaka. ${ }^{31} \mathrm{U}$ postupku utvrđivanja pravno-relevantnih činjenica sud izvodi u pravilu one dokaze koje predlože stranke, iako nije vezan tim dokaznim prijedlozima i često ih neće niti

ponovni postupak, svaka stranka snosi svoje troškove. Nastavno, rješenjem Visokog upravnog suda Republike Hrvatske Usž-35/18 od 14. lipnja 2018., zauzet je stav da stranka ima pravo na trošak samo ako je predmetna upravna stvar riješena u smislu odredbe članka 58. stavak 1. Zakona o upravnim sporovima.

29 Zakon o besplatnoj pravnoj pomoći, Narodne novine, br. 143/13. Prema članku 12. ovog Zakona sekundarna pravna pomoć obuhvaća: pravni savjet, sastavljanje podnesaka u postupku zaštite prava radnika pred poslodavcem, sastavljanje podnesaka u sudskim postupcima, zastupanje u sudskim postupcima, pravnu pomoć u mirnom rješenju spora, te oslobođenje od plaćanja troškova sudskog postupka i oslobođenje od plaćanja sudskih pristojbi. Rješenje o odobravanju pravne pomoći obuhvaća pravo na korištenje pojedinih ili svih oblika sekundarne pravne pomoći za postupak određene vrste i stupnja. Navedeno rješenje sadržava osobne podatke tražitelja besplatne pravne pomoći, kratak opis pravne stvari za koju je pravna pomoć odobrena, oblik i opseg odobrene pravne pomoći, podatke o odvjetniku koji će pružati pravnu pomoć te ostale podatke bitne za postupanje po rješenju navedene u Zakonu o besplatnoj pravnoj pomoći. Odobravanje pravne pomoći odnosi se na potpuno ili djelomično osiguravanje plaćanja troškova sekundarne pravne pomoći. Odobrena pravna pomoć može biti ograničena samo u slučajevima predviđenima Zakonom o besplatnoj pravnoj pomoći. Rješenjem o odobravanju pravne pomoći tražitelj besplatne pravne pomoći može biti oslobođen plaćanja troškova sudskog postupka (oslobođenje od polaganja predujma troškova svjedoka, tumača, vještaka, uviđaja i sudskih oglasa), troškova sudskih pristojbi i troškova s osnove naknade za rad odvjetnika u punom ili smanjenom opsegu.

30 Đerđa, D., Šikić, M., Komentar Zakona o upravnim sporovima uz uvodni članak Dragana Medvedovića, Zagreb, Novi informator, 2012., str. 204. Nastavno, navode da: „sud samostalno prosuđuje koje se činjenice trebaju utvrditi i odlučuje o dokazima na temelju kojih će se to učiniti. Sud nije vezan prijedlozima stranaka ni u pogledu činjenica koje treba utvrditi ni dokaza na temelju kojih se one mogu utvrditi. Sud se kao dokazom može koristiti svakim sredstvom koje smatra odgovarajućim za utvrđivanjem kakve činjenice“. Međutim, svakako treba naglasiti da sud, iako smatra neki dokaz oportunim provesti u konkretnoj upravnoj stvari, radi razjašnjenja koje odlučne činjenice, ograničen je u svom izboru ukoliko isti zahtijeva naknadu troška na teret sredstava suda. Iznimka je trošak sudskih tumača u postupcima odobravanja međunarodne i privremene zaštite i nezakonite migracije. Upravo zbog ograničenih mogućnosti suda, provođenje dokaza najčešće proizlazi iz prijedloga stranaka.

31 Čl. 34. st. 1. ZUS. 
prihvatiti, što ne znači samovolju u postupanju i proizvoljnost već podrazumijeva obvezu suda obrazložiti izbor dokaznog sredstva, odnosno iznijeti razloge odbijanja, jer će samo ako je stranka upoznata s razlozima izbora nekoga dokaznog sredstva biti zajamčeno njeno pravo na pristup sudu. Sud je ovlašten po službenoj dužnosti utvrđivati činjenice i izvoditi dokaze, ali samo one koji ne zahtijevaju predujmljivanje troškova iz sredstava suda. Smatramo da činjenica što sud zbog ograničenih sredstava ne može po službenoj dužnosti odrediti vještačenje, a što bi bilo svrsishodno za razjašnjenje neke pravno relevantne činjenice, uvažavajući ostale raspoložive dokaze, može imati za posljedicu poništavanje osporenog akta i vraćanje predmeta na ponovni postupak. Stoga se svojim inkvizitornim ovlaštenjem sud koristi radi pribavljanja isprava iz službenih evidencija javnopravnih tijela (koja nisu stranke u upravnom sporu), odnosno poziva stranke dostaviti određeni dokaz radi razjašnjenja neke činjenice (npr. dokaz radi li se o građevinskom ili poljoprivrednom zemljištu, i sl.). ${ }^{32}$ Prihvaćanjem dokaznog prijedloga za provođenje vještačenja po sudskom vještaku ostvaruje se kontradiktornost upravnog spora, jer se tako stranci pruža mogućnost očitovati se o odlučnim činjenicama, time što pokušava osporiti dokaze nepovoljne za ostvarenje njenog zahtjeva. Ponekad, u dvojbenim situacijama provesti vještačenje ili ne, smatramo da bi trebalo ići in favorem stranke i dati joj priliku djelotvorno osporiti utvrđenja javnopravnog tijela.

\subsection{Ocjena nalaza i mišljenja ovlaštenih vještaka u upravnom sporu}

Ako stranka ne predloži provesti dokaz vještačenjem, a kojim dokaznim sredstvom se jedino može osporiti nalaz i mišljenje ovlaštenih vještaka donesen u upravnom postupku, na zahtjev tijela koje rješava u nekoj upravnoj stvari, sud svoju odluku o zakonitosti osporenog akta može donijeti vrednovanjem svih prikupljenih dokaza kao i danih nalaza i mišljenja u oba provedena stupnja upravnog postupka po pravilima o slobodnoj ocjeni dokaza. Tako će prihvatiti nalaze i mišljenja ovlaštenih vještaka javnopravnog tijela samo ukoliko su dobro obrazloženi, razumljivi i jasni, te potkrijepljeni dokumentacijom priloženom u spisu tuženika, a dostavljenim dokazima uz tužbu stranka iste ne dovodi u sumnju.

O prihvatljivosti takvih nalaza i mišljenja, kao i prigovoru o eventualnoj neobjektivnosti ovlaštenih vještaka, obzirom su oni zaposlenici tih javnopravnih tijela, odnosno Zavoda za vještačenje, profesionalnu rehabilitaciju i zapošljavanje osoba s invaliditetom, ${ }^{33}$ zauzeo je stav Europski sud za ljudska prava.

32 B. Horvat zaključuje da regulacija upravnog spora isključivo stavlja naglasak na dokaznu inicijativu stranaka, gdje sud ima dopunjujuću i korektivnu ulogu, osobito ako se uzmu u obzir bitno različite temeljne pravne karakteristike parnice i upravnog spora, odnosno gotovo zauzet stav sudske prakse o sankcioniranju neaktivnosti stranaka u upravnom sporu. Horvat, B., Upravni spor od podnošenja tužbe do izvršenja - sporna pitanja u praksi, Zbornik radova Pravnog fakulteta u Splitu, god. 52, 1/2015., str. 233.

33 Zavod za vještačenje, profesionalnu rehabilitaciju i zapošljavanje osoba s invaliditetom osnovan je Zakonom o profesionalnoj rehabilitaciji i zapošljavanju osoba s invaliditetom (Narodne novine, br. 157/13., 152/14., 39/18.), kojim su, između ostalog, propisani poslovi vještačenja prema posebnim propisima radi utvrđivanja tjelesnog, intelektualnog, osjetilnog i mentalnog oštećenja, invaliditeta, funkcionalne sposobnosti, razine potpore te radne sposobnosti osobe. 
U presudi Zovko protiv Hrvatske ${ }^{34}$ Europski sud za ljudska prava utvrdio je da nije bilo povrede članka 6 . Konvencije prava na pošteno suđenje. U bitnome, podnositeljica zahtjeva pokrenula je postupak radi priznavanja prava na naknadu plaće za vrijeme bolovanja zbog bolesti kao posljedice priznate ozljede na radu. Isticala je da joj nije omogućeno sudjelovati u postupku, smatrajući da je bila u potpunosti isključena iz postupka vještačenja pred upravnim tijelom, te da je povrijeđeno načelo jednakosti oružja s obzirom na to da ju je Upravni sud u Zagrebu odbio saslušati i provesti neovisno medicinsko vještačenje radi utvrđivanja uzročne veze između njene bolesti i priznate ozljede na radu. Europski sud za ljudska prava u svojoj odluci primjećuje da je zahtjev podnositeljice razmatran pred upravnim tijelima $u$ dva stupnja, te potom pred Upravnim sudom u Zagrebu kao sudskim tijelom koje ima ovlast preispitati doneseni akt u svim aspektima - i činjeničnim i pravnim, te ističe da se odluka o osnovanosti zahtjeva temelji isključivo na nalazima medicinskih tijela vještačenja Hrvatskog zavoda za zdravstveno osiguranje. Europski sud je prihvatio argumente države da su vještaci upravnog tijela razmotrili sve prigovore podnositeljice vezane za njezino zdravstveno stanje, te na njih odgovorili na zadovoljavajući način, a da je podnositeljica bila obaviještena o rezultatima vještačenja, na njih se mogla očitovati, stoga je u dovoljnoj mjeri sudjelovala u postupku vještačenja. Činjenica da su vještaci zaposlenici Hrvatskog zavoda za zdravstveno osiguranje, i to medicinski eksperti sa značajnim profesionalnim iskustvom i obrazovanjem, nije dovoljna za dovođenje $u$ sumnju njihove nepristranosti, osim ukoliko stranka ne podnese dokaz kojim bi se njihov nalaz doveo u pitanje, što u konkretnom slučaju nije učinjeno. Osim toga, Europski sud naglašava da je uloga domaćeg suda ocijeniti je li konkretan nalaz vještaka pouzdan i vjerodostojan, dok je sukladno odredbama Konvencije njegova uloga razjasniti je li postupak kao cjelina, uključujući način ocjene dokaza, bio pravičan.

U predmetu Trbojević protiv Hrvatske ${ }^{35}$ Europski sud za ljudska prava odlučio je da je zahtjev podnositeljice gđe Trbojević zbog navodne povrede prava na pošteno suđenje očito neosnovan. Naime, podnositeljica zahtjeva je dio svojeg radnog vijeka provela u Republici Hrvatskoj, a dio u Kraljevini Norveškoj, te je pred Hrvatskim zavodom za mirovinsko osiguranje (dalje: HZMO) podnijela zahtjev za priznavanje prava na razmjerni dio invalidske mirovine. Podnositeljica je prigovarala da nije mogla sudjelovati u postupku vještačenja pred HZMO-om, da su vještaci bili pristrani jer su djelatnici HZMO-a, te da Upravni sud u Zagrebu nije naložio novo vještačenje niti saslušao vještake HZMO-a, pa je time povrijeđeno načelo jednakosti oružja. Sud se pozvao na stav zauzet u predmetu Zovko protiv Hrvatske o pitanju objektivnosti vještaka zaposlenih kod upravnih tijela, te je ponovio kako je riječ o visokoobrazovanim stručnjacima sa znatnim profesionalnim iskustvom koje domaće pravo obvezuje da nalaze daju nepristrano, stoga nalazi da u konkretnom slučaju nije podnesen dokaz koji bi ukazivao na suprotno. Sud je primijetio da je podnositeljica podnijela žalbu u odnosu na prvo od dva provedena vještačenja pred upravnim tijelom,

34 Zahtjev broj 56935/13, presuda od 23. svibnja 2017., konačna 23. kolovoza 2017. - Internet stranica https://hudoc.echr.coe.int

35 Zahtjev broj 57228/13, odluka od 7. lipnja 2018., - Internet stranica https://hudoc.echr.coe.int 
te da je viši vještak u drugom vještačenju razmotrio njezine konkretne prigovore, a da podnositeljica Upravnom sudu nije niti predložila provođenje neovisnog vještačenja. Naglašava da je prvenstveno na domaćem sudu da ocjenjuje relevantnost dokaza čije izvođenje u postupku stranka želi. Europski sud ne nalazi ništa nepravično u činjenici što je Upravni sud na raspravi odbio saslušati ovlaštenog višeg vještaka, stoga je odbacio podnositeljičin zahtjev kao očito neosnovan.

Dakle, prvenstveno je na sudu tijekom upravnog spora ocijeniti sve predložene dokaze te utvrditi koliko utječu na zakonitost osporenog akta. Norma o slobodnoj ocjeni dokaza ovlašćuje sud da u svakome konkretnom slučaju ocjenjuje ne samo koje od dokaznih sredstava upotrijebljenih u upravnom sporu i upravnom postupku daje uvjerljivije rezultate nego ujedno isključuje interpretaciju prema kojoj bi, npr. dokaz izveden u upravnom sporu samim time imao veću dokaznu snagu od dokaza izvedenog u upravnom postupku u kojem je donesena osporavana pojedinačna odluka (upravni akt). ${ }^{36}$ Iako su ovlašteni vještaci upravnih tijela nesporno visokoobrazovane i stručne osobe, ipak sudski vještaci u pojedinim slučajevima imaju posebne kvalifikacije i subspecijalnosti što čini njihov nalaz i mišljenje bolje obrazloženim $i$ argumentiranim.

\subsection{Ostvarenje načela jednakosti oruйja}

Uvažavajući načelo usmene rasprave, sud daje mogućnost strankama izjasniti se o predloženom vještačenju, osobi vještaka kao i o vrsti vještačenja koje bi se trebalo provesti te o činjenicama koje je potrebno tim vještačenjem utvrditi. Stranka predlaže vrstu vještačenja radi utvrđivanja ili razjašnjenja neke pravno-relevantne činjenice, o kojem prijedlogu sud odlučuje, ali nema ovlast usvojiti prijedlog stranke i odrediti neku drugu vrstu vještačenja koja nije predložena, iako bi to možda bilo svrhovitije u konkretnom predmetu. Naime, sud može strankama razjasnitij ${ }^{37}$ koje su relevantne činjenice u konkretnoj upravnoj stvari i kojim dokaznim sredstvima, odnosno vrstom vještačenja bi se iste mogle utvrditi, odnosno razjasniti, ali će odbiti prijedlog stranke ako se radi o vještačenju kojim se ne bi postigla željena svrha ili je ono u potpunosti irelevantno za donošenje odluke o zakonitosti osporenog akta. ${ }^{38} \mathrm{Sud}$ je ovlašten odrediti vještačenje čak i u slučaju protivljenja suprotne strane, uglavnom javnopravnog tijela-tuženika, koji „brani“ činjenična i pravna utvrđenja u donesenom upravnom aktu. Smatramo da je obveza suda točno i jasno odrediti zadatak vještaku,

36 Rajko, A., Neka pitanja u vezi s činjenicama i dokazivanjem u upravnom sporu, Pravo i porezi, br. 6, lipanj 2015., str. 26.

$37 \mathrm{U}$ ostvarivanju načela otvorenog pravosuđenja sud u raspravljanju o predmetu spora i predloženim dokazima iznosi svoja stajališta o pravnoj kvalifikaciji spora, o pravno-relevantnim činjenicama i o dokazima kojima bi se te činjenice mogle utvrditi.

38 Tako, primjerice Zakon o obveznom zdravstvenom osiguranju (Narodne novine, br. 80/13., 137/13.) u članku 67. propisuje razloge zbog kojih se neka ozljeda neće priznati ozljedom na radu. Između ostalog, ozljeda se neće priznati ukoliko je do ozljeđivanja došlo zbog skrivljenog, nesavjesnog ili neodgovornog ponašanja na radnome mjestu, odnosno pri obavljanju djelatnosti, kao i na redovitom putu od stana do mjesta rada i obrnuto. U opisanim slučajevima nije svrhovito provoditi medicinsko vještačenje na okolnost postoji li uzročno-posljedična veza između opisanog načina ozljeđivanja i zadobivene ozljede, te će se redovno takav dokazni prijedlog odbiti jer ne utječe na ishod upravnog spora. 
pri čemu je vezan materijalno-pravnim propisom koji regulira određenu upravnu materiju. Time se ostvaruje ne samo načelo učinkovitosti, izbjegavanjem dodatnih troškova strankama radi potrebe izrade dodatnog ili čak novog nalaza i mišljenja odnosno ukoliko se određenim vještačenjem uopće ne bi postigla željena svrha, već se time omogućava vođenje upravnog spora uz stvarno uvažavanje jednakosti oružja.

Neovisno o činjenici što je vještačenje u upravnom postupku provedeno u dva stupnja po ovlaštenim vještacima javnopravnog tijela, te su njihovi nalazi i mišljenja doneseni neposrednim pregledom stranke i medicinske dokumentacije koja prileži spisu, sud će usvojiti prijedlog stranke o provođenju neovisnoga sudskog vještačenja kada se navodima u tužbi osporava doneseni nalaz i izraženo mišljenje na kojem se temelji odluka upravnog tijela, radi pravilnog i potpunog utvrđenja spornih činjenica. Time se poštuje načelo jednakosti oružja, u smislu ravnoteže među strankama, jer se stranci (tužitelju) daje mogućnost izložene prigovore na utvrđeno činjenično stanje potkrijepiti dokazima, u odnosu na navode i utvrđenja suprotne strane, odnosno javnopravnog tijela. Bez omogućavanja stranci da se izvede predloženi dokaz vještačenjem i time provjeri pravilnost utvrđenog činjeničnog stanja iz upravnog postupka, smatramo da bi izostala stvarna sudska kontrola zakonitosti upravnih akata.

U predmetu Korošec protiv Slovenije ${ }^{39}$ Europski sud za ljudska prava ističe kako članak 6. Konvencije jamči pravo na pošteno suđenje, ali ne propisuje pravila o prihvatljivosti dokaza ili načina na koji se oni ocjenjuju, što je primarna zadaća nacionalnog prava i sudova. Ovaj članak ne priječi domaćim sudovima da prihvate nalaze ovlaštenih tijela vještačenja, međutim načelo jednakosti oružja, koje je jedan od elemenata prava na pošteno suđenje, zahtijeva da se svakoj stranci pruži razumna mogućnost da izlože činjenice i podupru ih svojim dokazima, u kojim uvjetima se niti jednu od stranaka ne stavlja u bitno lošiji položaj u odnosu na suprotnu stranku. Sud naglašava da u situaciji kada nalazi i mišljenja vještaka ovlaštenih tijela vještačenja imaju odlučujući utjecaj na ocjenu činjenica od strane suda jer su se odnosile na područje medicine koje nije bilo u sklopu sudačkog znanja, nedostatak neutralnosti imenovanog vještaka može u određenim situacijama dovesti do povrede načela jednakosti oružja. U predmetu Sara Lind Eggertsdóttir Sud je naglasio kako je potrebno uzeti u obzir tri čimbenika: prirodu zadatka koji je povjeren vještaku, njegov položaj u hijerarhiji suprotne strane i njegovu uloga u postupku, poglavito koju težinu pridaje sud danom nalazu. U konkretnom predmetu nalaz vještaka ovlaštenog tijela vještačenja (Zavoda za pokojninsko in invalidsko zavarovanje Slovenije) izravno je utjecao na odluku tijela o osnovanosti podnesenog zahtjeva, te se i odluka suda temeljila upravo na tom nalazu. Stoga je odbijanjem dokaznog prijedloga da se provede neovisno sudsko vještačenje i pruži mogućnost podnositelju zahtjeva osporavati doneseni nalaz, došlo do povrede članka 6 . Konvencije.

Ustavni sud Republike Hrvatske, razmatrajući je li došlo do povrede ustavnog prava na pravično suđenje iz članka 29. stavak 1 . Ustava ${ }^{40} \mathrm{u}$ odluci broj: U-III-2335/16

39 Zahtjev broj 77212/12, presuda od 8. listopada 2015., konačna 8. siječnja 2016., Internet stranica https://hudoc.echr.coe.int

40 Članak 29. stavak 1. Ustava Republike Hrvatske glasi: „Svatko ima pravo da zakonom ustanovljeni neovisni i nepristrani sud pravično i u razumnom roku odluči o njegovim pravima i obvezama, ili o sumnji ili optužbi zbog kažnjivog djela“. 
od 14. prosinca 2016. istaknuo je da se „konačna ocjena o uzroku invalidnosti podnositelja temelji na medicinskim nalazima i mišljenjima koji su dani za potrebe upravnog postupka od vještaka koji su zaposleni u upravnim tijelima Hrvatskog zavoda za mirovinsko osiguranje (dalje u tekstu: HZMO). Ti su nalazi i mišljenja odlučujući dokaz u ovom predmetu, jer se bez njih ne može dati procjena uzroka nastanka invalidnosti podnositelja. Ni sudovi ne posjeduju stručna medicinska znanja bez kojih se ne može procjenjivati nečije zdravstveno stanje, niti uzrok zbog kojega je netko nesposoban za rad. Uz to, u ovom predmetu, podnositelj je uz tužbu priložio presliku svog medicinskog kartona od rođenja pa do sada, a sudovi su sami (iako ne posjeduju stručnost liječnika) procijenili da taj dokaz ne može poslužiti pri ocjeni uzroka podnositeljeve invalidnosti/nesposobnosti za rad.

Kako je odlučujući dokaz u ovom postupku ostalo vještačenje provedeno po vještacima iz HZMO-a, može se zaključiti da podnositelju u upravnom sporu koji je vodio protiv javnopravnog tijela (koje se za potrebe ovoga postupka može izjednačiti s državom) nije dana mogućnost da dokazuje svoje tvrdnje, te da je upravni spor proveden bez stvarne namjere provedbe cilja upravnog spora - kontrole zakonitosti upravnih akata, a što je dužnost upravnih sudova propisanih člankom 19. stavkom 2. Ustava. Ovom odlukom Ustavni sud ne dovodi u pitanje načelo slobodne ocjene dokaza koje vrijedi za sudove u upravnom sporu. Osim toga, nije na Ustavnom sudu ocjenjivati koje odlučne činjenice redovni sudovi trebaju utvrđivati niti koje dokazne prijedloge stranaka moraju prihvaćati ili odbijati. Međutim, Ustavni sud napominje da je obveza sudova da, u cilju osiguranja pravičnog suđenja o pravima i obvezama stranaka, u postupku svakoj stranci omoguće da iznose dokaze kojima bi potkrijepile odnosno utvrdile svoje navode, a pogotovo one od kojih ovisi meritorno rješavanje spora (stajalište Ustavnog suda izraženo u odluci broj: U-III-3874/2008 od 4. travnja 2012.).“

Dakle, iz priloženih odluka Europskog suda za ljudska prava te Ustavnog suda Republike Hrvatske, razvidno je da u cilju ostvarivanja načela jednakosti oružja i pune afirmacije pristupa sudu, stranci mora biti omogućeno da osporava zaključke i stavove ovlaštenih vještaka $u$ provedenom upravnom postupku te da se njihovi nalazi podvrgnu stručnoj kritici sudskih vještaka, dok je sud dužan dati ocjenu svakog dokaza pojedinačno i u njihovoj ukupnosti, dajući za svoju odluku valjane razloge.

\subsection{Provedba vještačenja u upravnom sporu}

Usvajanjem prijedloga stranke o vrsti vještačenja koje će se provesti, sud prethodno mora omogućiti strankama izjašnjavanje o osobi vještaka, što proizlazi iz odredbe članka 251. ZPP-a. Sukladno navedenoj odredbi, stranka koja predlaže izvođenje dokaza vještačenjem može predložiti osobu vještaka, kojeg će sud i odrediti ako se protivna stranka ne usprotivi predloženom vještaku. U suprotnom, vještaka će odrediti sud, u pravilu, s liste stalnih sudskih vještaka. „Iako parnične stranke imaju pravo predložiti vještaka, ali sud nije vezan njihovim prijedlozima““41 „Kada sud

41 Odluka Ustavnog suda Republike Hrvatske broj: U-III/4214/2013 od 9. ožujka 2016., portal ius info 
odredi za vještačenje stručnjaka iz određene oblasti koji ima stručnu kvalifikaciju i znanje a stranke istom nisu prigovarale, tada nije odlučno što isti nije stalni sudski vještak“ ${ }^{42}$ Dakle, vještačenje obavljaju vještaci koje određuje sud, pa ,prvostupanjski sud nije mogao naložiti ovršeniku da dostavi sudu procjenu pokretnina izvršenu po sudskom vještaku kojeg isti sam odabere, već je to mogao učiniti samo vještak kojeg bi u konkretnom slučaju odredio sam sud upravo stoga jer se dokaz vještačenjem provodi kada je radi utvrđivanja ili razjašnjenja kakve činjenice potrebo stručno znanje kojim sud ne raspolaže". ${ }^{43}$

Kako prema članku 259.ZPP-a vještačenjem rukovodi sud, imenovanom vještaku potrebno je utvrditi zadaću, odnosno precizno odrediti što je predmet vještačenja i na koja sporna pitanja mora odgovoriti i, prema potrebi, tražiti objašnjenja u vezi s danim nalazom i mišljenjem. O načinu na koji je određen zadatak vještaku, te koliko je precizno dana naznaka na koja pitanja treba odgovoriti, ovisi i kvaliteta danog nalaza i mišljenja te hoće li se i u kojoj mjeri na tom nalazu i mišljenju moći temeljiti meritorna odluka suda.

Vještačenje se provodi $u$ svrhu da se utvrde i razjasne pravno-relevantne činjenice. Koje su to činjenice određuje materijalni propis koji se primjenjuje u konkretnoj upravnoj stvari, no ono što je bitno za rješavanje upravnog spora jest odrediti trenutak do kojeg se činjenice prikupljaju i do kada stranke mogu iznositi nove činjenice te posljedično koje činjenice mogu biti predmetom vještačenja. Predmetno pitanje je tema ne samo znanstvene analize već i rasprave među kolegama sucima. Tako Đerđa ${ }^{44}$ ističe da je relevantno činjenično stanje koje je postojalo u vrijeme donošenja pojedinačne odluke ili postupanja, stoga iznošenje činjenica koje su nastale nakon donošenja osporavane pojedinačne odluke ili postupanja ne utječe na rješavanje upravnog spora, osim u slučajevima propisanim zakonom, jer su takve činjenice osnova za ostvarivanje prava stranke u novom upravnom postupku..$^{45}$

Imajući u vidu jedinstvo upravnog postupka, te zakonom propisan predmet upravnog spora koji se u pretežnom broju slučajeva odnosi na ocjenu zakonitosti te posebno ustavom zajamčenu kontrolu upravnih akta koja se temelji na ideji o diobi vlasti uz uzajamne kontrole, u ovom slučaju sudske nad upravom, smatramo da nema osnove utvrđivati činjenice koje su nastale nakon donošenja osporenog rješenja. One

42 Županijski sud u Varaždinu, Gž-125/10-2 od 9. ožujka 2010., portal ius info

43 Županijski sud u Varaždinu, Gž-247/07-2 od 24. travnja 2007., portal ius info

44 Đerđa, D., Upravni spor, Pravni fakultet Sveučilišta u Rijeci, Rijeka, 2017., str. 99-100.

45 Isti stav iznosi i Bogdanović, T., Prvostupanjski upravni spor kao spor pune jurisdikcije u sudskoj praksi, Pravo i porezi, 6/2013., str. 33. Suprotno navedenom, B. Britvić Vetma smatra da bi u sporu pune jurisdikcije upravni sudac trebao donijeti odluku imajući u vidu činjenice i pravne elemente koji postoje na dan njegove odluke. Britvić Vetma, B., Spor pune jurisdikcije prema Zakonu o upravnim sporovima iz 2010., Zbornik Pravnog fakulteta Sveučilišta u Rijeci, vol. 32, 1/2011., str. 397. Raspravljajući o utvrđivanju relevantna činjeničnog stanja i o ovlastima suca u upravnom sporu, smatramo da se ne smije zaboraviti na Ustavom zajamčenu sudsku kontrolu zakonitosti pojedinačnih akata upravnih vlasti i tijela koja imaju javne ovlasti, a potom i na zakonsko definiranje predmeta upravnog spora, jer bi utvrđivanjem novonastalih činjenica o kojima upravno tijelo nije rješavalo, sud izašao iz ustavnih i zakonskih okvira. Samo je u predmetima međunarodne i privremene zaštite, zbog specifičnosti ovog upravnog područja, sud dužan utvrditi činjenično stanje u trenutku donošenja svoje odluke. 
mogu biti samo predmet novoga upravnog postupka, jer bi se u protivnom duboko narušila pravila o formalnoj i materijalnoj pravomoćnosti u upravnom postupku. S druge strane, u sudskom postupku rješavalo bi se o pravima i obvezama stranaka iz određenog upravnoga područja, a bez da se o istome izjasnilo javnopravno tijelo, za što dakako nema osnove u važećim propisima, a donesena presuda bila bi res iudicata.

\subsection{Zadatak sudskom vještaku}

Stranke pravilno predlože određenu vrstu vještačenja, međutim razloge zbog čega bi se trebalo provesti postavljaju jako široko i općenito, stoga bi u takvim slučajevima sud, prema načelu pomoći neukoj stranci, trebao precizirati zadatak vještaku, a sve kako bi se tim vještačenjem doista postigla zatražena svrha. Često se dostatno ne poznaju propisi iz određenog upravnog područja, što rezultira teškoćama u oblikovanju predloženih okolnosti o kojima bi se vještak trebao izjasniti. Tako, primjerice, nije dovoljno, u postupku radi ostvarivanja prava na temelju invalidnosti, predložiti vještačenje na okolnost „zdravstvenog stanja tužitelja“, već je potrebno razmotriti kako određeno zdravstveno stanje utječe na radnu sposobnost osobe te ocijeniti je li nastupila invalidnost u smislu zakonskih propisa, i u kojem trenutku. Također, u sporovima radi utvrđivanja poreza na promet nekretnina nije pravilno odrediti vještaku zadatak da „,procjeni tržišnu vrijednost nekretnine“, već ju je potrebno odrediti u odnosu na relevantni trenutak, odnosno na dan stjecanja predmetne nekretnine. ${ }^{46}$

„Sud mora vještaku odrediti zadatak vještačenja ovisno o tome koju činjenicu namjerava utvrditi vještačenjem. U konkretnom slučaju sud je vještaku odredio zadatak ,utvrditi pravo stanje duga“. Međutim, vještačenjem se ne može utvrđivati „pravo stanje duga“"već činjenice koje su odlučne za odlučivanje o tužbenom zahtjevu (u konkretnom slučaju ispravnost tužiteljevog obračuna ugovorne kamate, iznos neotplaćenog dijela kredita i slično). “47 Isto tako, u poreznim predmetima nije moguće odrediti vještačenje na okolnost je li izdani račun vjerodostojna isprava (koja potpuno $\mathrm{i}$ istinito odražava poslovni događaj), što je čest slučaj, jer se radi o pravnoj kategoriji za čiju je ocjenu nadležan sud, uzimajući u obzir sve okolnosti pojedinoga poslovnog događaja.

Precizno određenje predmeta i opsega vještačenja iznimno je važno za kasniju fazu razmatranja donesenog nalaza i mišljenja te njegova prihvaćanja kao valjana dokaza na kojem će se moći temeljiti meritorna, reformacijska odluka suda. Osim toga, time se smanjuje potreba za dopunama nalaza i mišljenja, pa tako i dodatnih troškova za stranke.

46 Zakon o porezu na promet nekretnina (Narodne novine br. 115/16.) definira tržišnu vrijednost nekretnine kao cijenu nekretnine koja se postiže ili se može postići na tržištu u trenutku nastanka porezne obveze. Porezna obveza nastaje u trenutku sklapanja ugovora ili drugoga pravnog posla kojim se stječe nekretnina (članak 16. stavak 1.).

47 Visoki trgovački sud Republike Hrvatske, Pž-5870/05 od 8. svibnja 2007. 


\subsection{Nalaz i mišljenje sudskog vještaka}

Prije početka vještačenja vještak se poziva da predmet vještačenja brižljivo razmotri, točno navede sve što opazi i nađe i da svoje mišljenje iznese savjesno i u skladu s pravilima znanosti i vještine, a upozorit će se i na posljedice davanja lažnog iskaza. ${ }^{48}$ Iskaz vještaka je lažan kada vještak u nalazu ne navede sve ono što je opazio i našao ili navede da je našao i opazio nešto što ne postoji, kao i onda kada u stručnom mišljenju protivno svojoj savjesti i poznavanju znanstvenih pravila, odnosno pravila struke, izvede nepravilne zaključke. ${ }^{49}$

U nalazu vještaka sadržani su podatci o svemu što je vještak zapazio ili otkrio vještačenjem (npr. popis medicinske dokumentacije, opis liječenja, karakteristike nekretnine - veličina, položaj i sl.). Na temelju tog nalaza, prema pravilima struke, iznosi mišljenje o utvrđenim činjenicama, te sukladno danom zadatku daje svoj zaključak (o tržišnoj vrijednosti nekretnine, o smanjenju radne sposobnosti uz preostalu radnu sposobnost, djelomičnom gubitku radne sposobnosti i potpunom gubitku radne sposobnosti, o trenutku kada je nastupio potpuni gubitak radne sposobnosti djeteta radi ostvarivanja prava na obiteljsku mirovinu i sl.).

Iako prema zakonskoj normi ${ }^{50}$ vještak može iznijeti svoj nalaz i mišljenje usmeno na raspravi, u praksi je uobičajeno da vještaci dostavljaju svoj nalaz i mišljenje isključivo u pisanom obliku koji se dostavlja strankama prije održavanja ročišta na kojem će se o njemu raspravljati. Vještak uvijek mora obrazložiti svoje mišljenje, a strankama se mora omogućiti sudjelovanje u raspravljanju o rezultatima vještačenja, u smislu odredbe članka 6 . Zakona o upravnim sporovima. ${ }^{51}$ Ukoliko to izneseni prigovori zahtijevaju, na raspravu će se pozvati vještak, kako bi se strankama omogućilo da vještaku postavljaju pitanja i traže objašnjenja u svezi s danim nalazom i mišljenjem. Ipak, na raspravu se neće pozivati vještak kada se stranke izjasne da nemaju primjedbi na dostavljeni nalaz i mišljenje, odnosno, ako se uopće ne očituju na dostavljeni nalaz i mišljenje ili je dostavljeno očitovanje općenito bez navođenja konkretnih primjedbi. Kada sud smatra da bi vještak trebao dopuniti svoj nalaz i mišljenje ili su potrebna dodatna razjašnjenja, pozvat će ga pisanim putem na dopunu, o kojoj će se strankama također dati pravo na očitovanje.

\subsection{Ocjena nalaza i mišljenja sudskog vještaka}

Sud slobodno ocjenjuje dokaze i utvrđuje činjenice, ${ }^{52}$ a dokaznu vrijednost vještačenja ocjenjuje na temelju savjesne i brižljive ocjene svih dokaza zajedno i na temelju rezultata cjelokupnog postupka. S time u svezi obveza je suda u obrazloženju presude navesti koje su činjenice utvrđene vještačenjem, zašto i kako su utvrđene,

48 Čl. 258. st. 1. ZPP.

49 Čizmić, J., O vještačenju u parničnom postupku s posebnim osvrtom na vještačenje u području medicine, Zbornik Pravnog fakulteta Sveučilišta u Rijeci, vol. 32, 1/2011., str. 488.

50 Čl. 260. st. 1. ZPP.

51 Čl. 6. glasi: „Prije donošenja presude sud će svakoj stranci dati mogućnost izjasniti se o zahtjevima i navodima drugih stranaka te o svim činjenicama i pravnim pitanjima koja su predmet upravnog spora".

52 Čl. 33. st. 1. Zakona o upravnim sporovima. 
te kako su cijenjeni izvedeni dokazi zasebno i u njihovoj ukupnosti. Sud nije vezan ni stručnim nalazom niti mišljenjem vještaka, i može ih, vodeći se pravilima logike, podvrgnuti analizi i kritici. ${ }^{53}$ Smatramo da kritici svakako treba podvrgnuti nalaz i mišljenje ukoliko vještak izađe izvan okvira zadanog mu naloga.

Značaj sudskog nalaza i mišljenja ima samo nalaz i mišljenje vještaka kojeg je u tom svojstvu odredio sud i kojem je sud dao zadatak. „Nalazi i mišljenja, iako sudskih vještaka, ali izrađeni po nalogu stranke, nemaju značaj sudskog nalaza već samo privatne isprave dostavljene na spis predmeta, te se svakoj stranci mora dati mogućnost očitovati se na primljenu ispravu. Dokazno sredstvo kojim se dokazuje osnovanost činjeničnih tvrdnji stranaka predstavlja samo onaj nalaz i mišljenje vještaka kojega je u tom svojstvu odredio sud u konkretnoj parnici, iz kojeg razloga sud nije dužan nalaz i mišljenje vještaka koji je tužitelj priložio uz tužbu, te koji je sačinjen po nalogu tužitelja, prihvatiti samo stoga što je isti dan od strane osobe koja je stalni sudski vještak". ${ }^{54}$

O istome se izjasnio i Visoki trgovački sud Republike Hrvatske navodeći da „,premda je i vještak mr. sc. I. T. također iz redova sudskih vještaka, njegov pisani nalaz i mišljenje nije zatražio sud. Stoga njegov pisani nalaz i mišljenje u konkretnom slučaju nemaju dokaznu snagu sudskog vještačkog nalaza. Ovaj pisani nalaz i mišljenje predstavlja privatnu ispravu pribavljenu s tužiteljeve strane, koja također predstavlja valjano dokazno sredstvo. Međutim, privatne isprave, za razliku od javnih, ne tvore predmnijevu istinitosti, pa ih sud treba vrednovati i ocijeniti u sklopu svih ostalih provedenih dokaza, a ujedno i omogućiti suprotnoj stranci očitovati se o njenom sadržaju. Tek za slučaj da su spomenuti pisani nalaz i mišljenje dostavljeni tuženiku, te da se on o njihovom sadržaju ni na jedan način nije usprotivio ili da nije zatražio dodatno očitovanje vještaka ili novo vještačenje, prvostupanjski sud bi ga sukladno pravilu o teretu dokazivanja mogao prihvatiti kao dokaz čija valjanost nije dovedena u pitanje i tek potom na njemu utemeljiti pobijanu presudu“" 55

\section{FUNKCIJA VJES̆TAČENJA U UPRAVNOM SPORU}

Vještak je vezan zadatkom koji mu je odredio sud, te mu dostavlja i spis tuženika u kojem se nalazi dokumentacija koja je predmet vještačenja (medicinska dokumentacija stranke, podatci o nekretnini, vozilu i sl.). Naime, u spisu predmeta tuženika priložene su isprave i prikupljeni dokazi (zapisnici o provedenim raspravama, saslušanim svjedocima, nalazi i mišljenja ovlaštenih vještaka,) u svrhu utvrđivanja činjeničnog stanja temeljem kojeg se donosi odluka nakon provedenog upravnog postupka. Uvid u spis tuženika u postupku vještačenja posebno je važan jer vještak u pravilu daje svoj nalaz i mišljenje o činjenicama koje su postojale u vrijeme vođenja upravnog postupka i sukladno dokumentaciji priloženoj u spisu koja je bila temelj za donošenje osporavane odluke. ${ }^{56}$ Time, u biti, sudski vještak u upravnom sporu dobiva

53 Čizmić, O vještačenju, op. cit., str. 489.

54 Županijski sud u Varaždinu, Gž-1652/05 od 3. studenog 2005., portal ius info.

55 Visoki trgovački sud Republike Hrvatske, Pž-6184/06 od 14. ožujka 2007., portal ius info.

56 Kako pravila upravnog postupka ne poznaju materijalnu nego samo formalnu pravomoćnost, 
posebnu (kontrolnu) funkciju jer daje svoj nalaz i mišljenje o istim stručnim pitanjima o kojima se raspravljalo pred upravnim tijelom. Ovo stoga što za razliku od parničnog postupka, u upravnom sporu sud uzima u obzir i činjenice utvrđene u postupku donošenja osporene odluke, kojima nije vezan, i činjenice koje je sam utvrdio. ${ }^{57}$

Ocjenjujući utvrđene činjenice i provedeni dokazni postupak, u upravnim stvarima u kojima je vještačenje provedeno i u upravnom postupku, po ovlaštenim vještacima upravnog tijela, sud je obvezan kritički ocijeniti doneseni nalaz i mišljenje ovlaštenog vještaka kao i nalaz i mišljenje stalnoga sudskog vještaka donesen tijekom upravnog spora te iznijeti razloge zbog kojih prihvaća zaključke ovlaštenog ili sudskog vještaka i kome priklanja vjeru, posebno kada su oni suprotni.

O važnosti ocjene činjenica koje je utvrđivalo upravno tijelo i o kojima se moglo izjasniti provodeći upravni postupak, te o nužnosti ocjene nalaza i mišljenja ovlaštenog vještaka u odnosu na nalaz i mišljenje sudskog vještaka, kao i prihvatljivost nalaza i mišljenja sudskog vještaka kada izlazi iz vremenskog okvira činjenica koje su postojale do donošenja osporenog akta izjasnio se Visoki upravni sud Republike Hrvatske ${ }^{58}$ navodeći da je ,predmet upravnog spora, između ostalog, ocjena zakonitosti pojedinačne odluke kojom je javnopravno tijelo odlučilo o stanovitom pravu ili obvezi, protiv koje odluke nije dopušteno izjaviti redoviti pravni lijek (članak 3. stavak 1. točka 1. ZUS-a). Iz navedene odredbe, proizlazi da upravnom sporu prethodi upravni postupak, u kojem je donijeto rješenje protiv kojeg nije dopušteno izjaviti redoviti pravni lijek, te nezadovoljna stranka može tužbom pokrenuti upravni spor pred nadležnim sudom (članak 22. stavak 1. ZUS-a). Nakon što sud ocijeni urednost tužbe, nadležnost i pretpostavke za vođenje upravnog spora (članci 27., 28., 29. i 30. ZUS-a) sud odlučuje o tužbenom zahtjevu na način da ocjenjuje dokaze i utvrđuje činjenice, pri čemu uzima u obzir činjenice utvrđene u postupku donošenja osporene odluke kojima nije vezan i činjenice koje je sam utvrdio (članak 33. stavak 1. i 2. ZUS-a). $\mathrm{U}$ tom pravcu upravni sud ocjenjuje, jesu li činjenice u upravnom postupku pravilno sublimirane na pravnu normu, te je li obrazloženje rješenja cjelovito, konzistentno i logično. Dakle, zadaća upravnog suda je da utvrdi, je li rješenje tuženika koje je predmet upravnog spora, zakonito, te o tomu dade valjano obrazloženje, ako nije zakonito, zbog čega smatra da nije zakonito a ako jeste zakonito, zbog čega smatra da jeste zakonito.

U ovom upravnosudskom sporu sud je rješenja tuženika i prvostupanjskog

te stranka ima pravo (ponekad i nebrojeno puta) ponovno podnijeti novi zahtjev u slučaju negativne odluke, sud treba biti oprezan po pitanju činjenica koje vještačenjem utvrđuje kako ne bi prekoračio zakonom dane ovlasti, niti prekršio Ustavom zajamčenu sudsku kontrolu uprave i načelo diobe vlasti kroz uzajamne suradnje i provjere. Također i Bogdanović, T. ističe ako bi se Zakon o upravnim sporovima tumačio na način da sud može utvrđivati i naknadno nastale činjenice, $\mathrm{tj}$. one činjenice koje nisu postojale do donošenja osporavanog rješenja, sud bi prešao granice predmeta upravnog spora propisanog Zakonom o upravnim sporovima u vidu ocjene zakonitosti pojedinačnog akta ili postupanja javnopravnog tijela, te bi time doveo stranke u situaciju sudski presuđene stvari koja onda, prema logici stvari, više ne bi mogla biti predmetom upravnog postupka. Bogdanović, T., op. cit., str. 33.

57 Čl. 33. st. 2. Zakona o upravnim sporovima.

58 Presuda Usž-3880/17. od 10. svibnja 2018., koju zbog značaja zauzetog stava smatramo svrhovitim citirati u većem dijelu. 
javnopravnog tijela, ocijenio nezakonitim, jer se temelje na nalazima i mišljenjima stručnih tijela medicinskog vještačenja u upravnom postupku, a koji nalazi stručnih tijela medicinskog vještačenja nisu istovjetni sa nalazom i mišljenjem sudskog vještaka prof. dr. sci. B.M., dr. med., čiji nalaz je sud prihvatio kao valjan i na kojem temelji odluku, da je kod tužitelja nastupila opća nesposobnost za rad dana 5. rujna 2016. Prigovore tijela medicinskog vještačenja u upravnom postupku, da je vještačena medicinska dokumentacija nastala nakon upravnog postupka i donošenja osporenih rješenja, sud je obrazložio navodima da „opća nesposobnost za rad tužitelja koja je nastupila nakon okončanja upravnog postupka nije razlog da ovaj sud odbije tužbeni zahtjev", jer se tako ubrzava ostvarivanje prava tužitelja, što je intencija ZUS-a. Potom sud ocjenjuje da je u upravnom postupku na pogrešan način utvrđeno činjenično stanje i povrijeđeno materijalno pravo, zbog čega je poništio rješenja tuženika kao nezakonita.

U obrazloženju presude Upravnog suda u Zagrebu, nema razloga zbog čega sud smatra da su nalazi i mišljenja stručnih tijela medicinskog vještačenja data $\mathrm{u}$ upravnom postupku, neosnovana, neutemeljena, zapravo u tom pravcu nema očitovanja suda. Sud prihvaća nalaz i mišljenje sudskog vještaka, dato temeljem medicinske dokumentacije nastale nakon upravnog postupka i donošenja osporenih rješenja 9. prosinca 2013. i 28. travnja 2014. sa utvrđenjem da je došlo do pogoršanja zdravstvenog stanja, pa zbog ekonomičnosti postupka, sud je odlučio, da će bez provođenja upravnog postupka, u vremenu od 5. prosinca 2013. kada je u upravnom postupku tužitelj pregledan, pa do 5. rujna 2016. godine, kada je tužitelj pregledan u upravnom sporu od strane sudskog vještaka, donijeti odluku o pravu iz mirovinskog osiguranja, bez prethodnog provođenja upravnog postupka, držeći da je to intencija ZUS-a.

Na ovaj način sud je počinio bitne povrede odredbi ZUS-a i ZUP-a, kada je odlučio o pravu tužitelja, bez prethodno provedenog upravnog postupka za navedeno razdoblje od 2013. do 2016. godine, bez podnesenog zahtjeva za postupanje upravnom tijelu u tom periodu, što je razlog ništetnosti, bez da je upravno tijelo donijelo konačnu odluku o pravu u tom periodu, i bez zakonske osnove za takovo postupanje suda.

Sukladno odredbi članka 3. stavak 1. točke 1. ZUS-a, predmet upravnog spora, je ocjena zakonitosti odluke javnopravnog tijela protiv koje nije dozvoljeno izjaviti pravni lijek, kada je protiv takove odluke pokrenut upravni spor, sukladno članku 22. ZUS-a. Sud je time povrijedio načelo zakonitosti iz članka 5. ZUS-a, jer se postupanje suda i donijeta odluka suda, ne temelji na procesnim i na materijalnim odredbama ZUS-a i Zakona o mirovinskom osiguranju - ZoMO/98.

Osnovano tuženik ukazuje na povrede odredaba ZoMO/98 i to članka 115. stavak 1. koji propisuje, da se kao dan nastanka invalidnosti uzima dan kada je na temelju pregleda ovlaštenog vještaka dano mišljenje u smislu članka 113. stavak 1. tog Zakona, a iznimno prije toga. Dakle, ni u kom slučaju, ne tri godine nakon provedenog vještačenja u upravnom postupku, i donijetih odluka tuženika. U postupku ostvarivanja prava iz mirovinskog osiguranja primjenjuju se odredbe ZUP-a, ako ZoMO/98 nije drukčije odredio (članak 9. stavak 1. i 2. ZoMO/98), a o pravu iz mirovinskog osiguranja rješava nadležna Područna ustrojstvena jedinica 
Zavoda, a u drugom stupnju tuženik (članak 105. ZoMO/98) i to po osnovi zahtjeva za ostvarivanje prava, koji podnosi osiguranik ili u povodu prijedloga izabranog doktora medicine primarne zdravstvene zaštite.

Od donošena osporenog akta tuženika 28. travnja 2014., do 5. rujna 2016. godine, kada je sudski vještak pregledao osiguranika-tužitelja i utvrdio invalidnost, nije vođen upravni postupak, sukladno odredbama ZoMO/98, te stoga sud nije ni mogao ocjenjivati zakonitost nepostojećeg upravnog akta i upravnog postupka, sukladno članku 3. stavka 1. točke 1. ZUS-a.“

Iz citirane presude jasno je vidljiva uloga vještačenja u upravnom sporu kojom se omogućuje stranci osporiti utvrđenje upravnog tijela te doneseni zaključak o činjenicama koje su bile predmet upravnog postupka.

\subsection{Položaj ovlaštenih vještaka u upravnom sporu}

Zakon o općem upravnom postupku te naročito posebni materijalni propisi ${ }^{59}$ reguliraju položaj ovlaštenog vještaka u postupku koji se provodi pred upravnim tijelom. Međutim, u upravnom sporu njegova uloga nije propisana i svodi se na „stručnog pomagača“ tuženika u „obrani“ donesenog akta. Ovlašteni vještak ${ }^{60}$ nema status sudskog vještaka jer ga nije odredio sud niti mu je dao zadatak, stoga može biti pozvan na raspravu samo kao stručna osoba koja je sudjelovala u upravnom postupku, pa se njegov iskaz cijeni u kontekstu svih ostalih provedenih dokaza. Stoga u situacijama kada su oprečni nalazi i mišljenja ovlaštenog vještaka sačinjenog u upravnom postupku i sudskog vještaka danog po nalogu suda, na raspravu se mora pozvati sudski vještak kako bi otklonio prigovore i razložio nejasnoće, dok je uloga suda ocijeniti sve dokaze, pravilnost utvrđenja činjeničnog stanja u upravnom postupku i onog kojeg je sam utvrdio, formirati svoj stav i donijeti odluku o zakonitosti osporenog akta. Za razliku od parničnog postupka, upravni sud, ukoliko na temelju provedenoga sudskog vještačenja neku činjenicu ipak ne bi mogao nesporno utvrditi, niti bi mogao donijeti reformacijsku odluku u konkretnoj upravnoj stvari, ovlašten je donijeti kasatornu odluku i poništiti osporeni akt te vratiti predmet na ponovni

59 Zakon o profesionalnoj rehabilitaciji i zapošljavanju osoba s invaliditetom, Uredba o metodologijama vještačenja (Narodne novine, br. 67/17., 56/18.), Zakon o obveznom zdravstvenom osiguranju (Narodne novine, br. 80/13., 137/13.), Pravilnik o pravima, uvjetima i načinu ostvarivanja prava iz obveznoga zdravstvenog osiguranja u slučaju ozljede na radu i profesionalne bolesti (Narodne novine, br. 75/14., 154/14., 79/15., 139/15.), itd.

60 Ovlašteni vještakjezaposlenikZavoda za vještačenje, profesionalnu rehabilitacijuizapošljavanje osoba s invaliditetom, te se vještačenje provodi na zahtjev nadležnog tijela koje odlučuje o pravima u području socijalne skrbi, mirovinskog osiguranja, profesionalne rehabilitacije i zapošljavanja osoba s invaliditetom, prava po osnovi rodiljnih i roditeljskih potpora, zaštite ratnih i civilnih žrtava rata te u svrhu utvrđivanja psihofizičkog stanja djeteta pri ostvarivanju prava u sustavu obrazovanja, kao i u svrhu ostvarivanja prava u drugim područjima u kojima se prava ostvaruju na temelju nalaza i mišljenja tijela vještačenja kada je to propisano zakonom. U ovim se predmetima vještačenje provodi na temelju metodologija za utvrđivanje tjelesnog, intelektualnog, osjetilnog i mentalnog oštećenja, invaliditeta, funkcionalne sposobnosti, razine potpore te radne sposobnosti osobe. Nadalje, može se reći da i službenik Porezne uprave u postupcima procjene tržišne vrijednosti nekretnine također ima status ovlaštenog vještaka za procjenu. 
postupak tijelu s jasnom uputom kako provesti postupak i koji dokaz izvesti, radi otklanjanja nejasnoća. „Neuspjeh da se nešto riješi vještačenjem na potrebnoj razini uvjerenosti treba jednako tretirati kao i slučajeve u kojima nema dovoljno drugih dokaza da se sa sigurnošću zaključi o postojanju ili nepostojanju neke činjenice."“61

\subsection{Odnos provedenog vještačenja u upravnom postupku i и upravnom sporu}

$\mathrm{O}$ odnosu vještačenja u upravnom postupku u odnosu na ulogu vještačenja $u$ upravnom sporu izjasnio se Visoki upravni sud Republike Hrvatske ${ }^{62}$ navodeći da se „odredbe materijalnog propisa, konkretno ZOMO-a, u svezi utvrđivanja medicinski relevantnih činjenica odnose na provođenje upravnog postupka i po njima je dužno postupati javnopravno tijelo koje odlučuje o pravu ili obvezi stranke i koje svoje odluke temelji na nalazima i mišljenjima institucionaliziranih tijela vještačenja. Međutim, u upravnom sporu, koji se, među ostalim, vodi radi kontrole zakonitosti donošenja pojedinačnih odluka, kad sud utvrdi da je osporena odluka javnopravnog tijela nezakonita, spor o ocjeni zakonitosti pojedinačne odluke javnopravnog tijela može se pretvoriti u spor pune jurisdikcije u kojemu sud sam rješava predmetnu upravnu stvar. Sud je, pritom, radi potpunog i pravilnog utvrđenja spornih činjenica, ovlašten provesti dokaz vještačenjem po sudskom vještaku, rezultat kojeg vještačenja, ovisno o ocjeni suda, može biti temelj za rješavanje o pravu ili obvezi stranke.“

Nastavno, Visoki upravni sud Republike Hrvatske ${ }^{63}$ izjasnio se o pravilnosti meritorne odluke donesene nakon što je u prvostupanjskom upravnom sporu sud na okolnost utvrđivanja tržišne vrijednosti nekretnine odredio provođenje vještačenja po sudskom vještaku za graditeljstvo i procjenu nekretnina. „Prvostupanjski upravni sud je strankama u sporu dostavio nalaz i mišljenje sudskog vještaka te ih je pozvao da se očituju u roku od 8 dana. Tuženik se očitovao na način da je istaknuo kako je u skladu s člankom 9. stavkom 6. Zakona o porezu na promet nekretnina Porezna uprava ovlaštena procjenom utvrditi tržišnu vrijednost nekretnina, da je prvostupanjsko tijelo sastavilo zapisnik u kojem je dalo jasan, potpun i dovoljno obrazložen nalaz iz kojeg je vidljivo temeljem kojih bitnih elemenata je utvrđena tržišna vrijednost predmetne nekretnine te da Porezna uprava prilikom utvrđivanja tržišne vrijednosti nekretnine nije vezana nalazima i mišljenjima vještaka. Po ocjeni Visokog upravnog suda Republike Hrvatske, prvostupanjski sud je u skladu s odredbom članka 33. ZUS-a, na prijedlog tužitelja, izveo dokaz vještačenjem tržišne vrijednosti nekretnine te je na temelju tog nalaza i mišljenja donio odluku. Tuženik nije osporavao nalaz i mišljenje sudskog vještaka, već je istakao da je Porezna uprava ovlaštena utvrđivati tržišnu vrijednost nekretnine. No to se ovlaštenje odnosi na upravni postupak. Međutim, cilj upravnog spora je osigurati sudsku zaštitu prava i pravnih interesa stranaka (čl. 2. st. 1. ZUS-a), dakle provesti sudski postupak po pravilima propisanim ZUS-om. Predmet upravnog spora je, među ostalim i ocjena zakonitosti odluke kojom je javnopravno tijelo odlučilo o pravu, obvezi ili pravnom interesu stranke u upravnoj stvari (čl. 3.

61 Dika, M., op. cit., str. 674-675.

62 Visoki upravni sud Republike Hrvatske, Usž-711/16 od 21. travnja 2016., portal SupraNova.

63 Visoki upravni sud Republike Hrvatske, Usž-634/14-7 od 22. siječnja 2015., portal SupraNova. 
st. 1. t. 1. ZUS-a). S obzirom na navedeno, sud je ovlašten ocjenjivati zakonitost provedenog upravnog postupka koji je prethodio donošenju odluke koju ocjenjuje te pri tom slobodno ocjenjivati izvedene dokaze i utvrđivati činjenice, služeći se svim zakonom propisanim dokaznim sredstvima. Naime, sud samostalno prosuđuje koje se činjenice trebaju utvrditi i odlučuje o dokazima na temelju kojih će to učiniti, po pravilima o dokazivanju u parničnom postupku na koja ZUS izravno upućuje (čl. 33. st. 5. ZUS-a). Stoga je prvostupanjski sud na izloženo činjenično stanje pravilno primijenio materijalno pravo te usvojio tužbeni zahtjev, poništio oba rješenja i sam riješio stvar."

Da bi sud mogao u cijelosti ostvariti svoju svrhu i omogućiti stvarno ispunjenje načela jednakosti oružja smatramo da je dužan prihvatiti prijedlog stranke i u upravnom sporu provesti neovisno sudsko vještačenje, osobito u situaciji kada stranka svojim tužbenim navodima osporava nalaz i mišljenje ovlaštenih vještaka tuženika na kojem se temelji osporavana odluka. U takvoj situaciji nema zapreke da nalaz i mišljenje neovisnog vještaka dan pred sudom, kao rezultat primjene slobodne dokazne maksime, bude temelj za donošenje reformacijske presude.

\section{ZAKLJUČAK}

Upravni spor se u bitnome razlikuje od parničnog postupka osobito u dijelu utvrđivanja činjeničnog stanja kao i izbora dokaznog sredstva. Naime, dokazni postupak ne počinje tek upravnim sporom, već je isti proveden pred upravnim tijelom u pravilu u dva stupnja, stoga je uvid suda u dostavljeni spis predmeta upravnog postupka često jedini izvedeni dokaz. Sud izvodi dokaze prema pravilima kojima je uređeno dokazivanje u parničnom postupku, no izbor dokaznog sredstva usmjeren je na utvrđenje i/ili razjašnjenje sporne činjenice ili spornog pitanja koje je ostalo otvoreno nakon provedenoga upravnog postupka.

Imajući u vidu jedinstvo upravnog postupka, te zakonom propisan predmet upravnog spora koji se u prevladavajućem broju slučajeva odnosi na ocjenu zakonitosti donesenog upravnog akta, a posebno ustavom zajamčenu sudsku kontrolu upravnih akta koja se temelji na ideji o diobi vlasti, u ovom slučaju sudske nad upravnom, smatramo da nema osnove utvrđivati činjenice koje su nastale nakon donošenja osporenog rješenja. Takve činjenice mogu biti predmet samo novog upravnog postupka, jer bi se u protivnom duboko narušila pravila o formalnoj i materijalnoj pravomoćnosti u upravnom postupku. $\mathrm{S}$ druge strane, u sudskom postupku rješavalo bi se o pravma i obvezama stranaka iz određenog upravnog područja, za što dakako nema osnove u važećim propisima, a donesena sudska presuda bila bi za stranke res iudicata.

Slijedom navedenog, ističe se kako se vještačenje u upravnom sporu može odrediti u svrhu provjere pravilnosti utvrđenih činjenica o kojima je upravno tijelo izvelo svoj zaključak i donijelo osporeno rješenje. Tek u tom slučaju nalaz i mišljenje sudskog vještaka, koji je podvrgnut kritičkoj ocjeni suda i raspravi među strankama, može biti valjana osnova za donošenje meritorne, reformacijske odluke u sporu pune jurisdikcije, a bez opasnosti da se prekorače ustavom i zakonom dane ovlasti. Za 
takvu odluku suda smatramo da nema zapreke niti kada posebni materijalni propisi iz određenog upravnog područja propisuju ekskluzivitet za utvrđenje činjenica od strane ovlaštenih vještaka tih tijela, jer bi u protivnom izostala uloga sudskog nadzora.

Vještačenje u upravnom sporu učinkovito je dokazno sredstvo, koje ne samo da ima za cilj omogućiti strankama u punom smislu ostvarenje prava na pravično suđenje i pristup sudu, nego je u nekim predmetima i jedino učinkovito oružje kojim stranke mogu osporavati utvrđenja javnopravnog tijela, osobito kada se ona temelje na ocjenama ovlaštenih vještaka u upravnom postupku, tim više što važeći zakonski propisi omogućuju i strankama slabijeg imovnog stanja predujmiti potrebna sredstva za provođenje ovoga dokaznog sredstva.

Kada bi sud onemogućio strankama izvođenje dokaza vještačenjem izostala bi sudska kontrola zakonitosti akta javnopravnog tijela, i to ne samo u procesnom smislu zbog povrede pravila postupka, a time i načela jednakosti oružja, nego još i važnije u materijalnopravnom aspektu kojem je svrha potpuno i pravilno utvrđenje činjeničnog stanja. Da bi se postigla pravična procesna ravnoteža između stranaka i pouzdano utvrdile činjenice konkretnog slučaja, smatramo da sud treba pomoći stranci u oblikovanju zadatka vještaku uvažavajući relevantne odredbe materijalnog propisa koji regulira određenu upravnu materiju. Tek tada neće biti osnove za zaključak da su provedenim upravnim sporom i donesenom presudom povrijeđene odredbe Ustava Republike Hrvatske i Europske konvencije za zaštitu ljudskih prava i temeljnih sloboda.

\section{LITERATURA}

Knjige i članci:

1. Bestvina, Melita, Balić, Đorđe, Imenovanje sudskih vještaka i procjenitelja u RH i ostalim susjednim državama, Simpozij o izvlaštenju nekretnina, Zagreb, 13. listopada 2018.

2. Bogdanović, Tamara, Prvostupanjski upravni spor kao spor pune jurisdikcije u sudskoj praksi, Pravo i porezi, 6/2013.

3. Britvić Vetma, Bosiljka, Spor pune jurisdikcije prema Zakonu o upravnim sporovima iz 2010., Zbornik Pravnog fakulteta Sveučilišta u Rijeci, vol. 32, 1/2011., str. 381-402.

4. Čizmić, Jozo, O vještačenju u parničnom postupku s posebnim osvrtom na vještačenje u području medicine, Zbornik Pravnog fakulteta Sveučilišta u Rijeci, vol. 32, 1/2011., str. 473-508.

5. Dika, Mihajlo, Građansko parnično procesno pravo - Utvrđivanje činjenica, VII. knjiga, Zagreb, Narodne novine, 2018.

6. Đerđa, Dario, Upravni spor, Rijeka, Pravni fakultet Sveučilišta u Rijeci, 2017.

7. Đerđa, Dario, Šikić, Marko, Komentar Zakona o upravnim sporovima, uz uvodni članak Dragana Medvedovića, Novi sustav upravnog sudovanja, Zagreb, Novi informator, 2012.

8. Horvat, Božidar, Upravni spor od podnošenja tužbe do izvršenja - sporna pitanja u praksi, Zbornik radova Pravnog fakulteta u Splitu, god. 52, 1/2015., str. 221-242.

9. Poznić, Borivoje, Vražalić, Mihajlo, Bačić, Franjo, Zakon o parničnom postupku s komentarom, Beograd, Nova administracija, 1957.

10. Rajko, Alen, Neka pitanja u vezi s činjenicama i dokazivanjem u upravnom sporu, Pravo i porezi, broj 6, lipanj 2015., str. 25-29.

11. Triva, Siniša, Dika, Mihajlo, Građansko parnično procesno pravo, 7. izmijenjeno i dopunjeno izd., Zagreb, Narodne novine, 2004. 
Pravni propisi:

1. Konvencija za zaštitu ljudskih prava i temeljnih sloboda Vijeća Europe, Narodne novine - Međunarodni ugovori, br. 18/97., 6/99., 14/02., 13/03., 9/05., 1/06., 2/10.

2. Pravilnik o stalnim sudskim vještacima, Narodne novine, br. 38/14., 123/15., 29/16.

3. Ustav Republike Hrvatske, Narodne novine, br. 56/90., 135/97., 8/98., 113/00., 124/00., 28/01., 41/01., 76/10., 85/10., 5/14.

4. Zakon o parničnom postupku, Narodne novine, br. 53/91., 91/92., 112/99., 129/00., 88/01., 117/03., 88/05., 2/07., 96/08., 84/08., 123/08., 57/11., 25/13., 89/14.

5. Zakon o profesionalnoj rehabilitaciji i zapošljavanju osoba s invaliditetom, Narodne novine, br. 157/13., 152/14., 39/18.

6. Zakon o sudovima, Narodne novine, br. 28/13., 33/15., 82/15., 82/16.

7. Zakon o upravnim sporovima, Narodne novine, br. 20/10., 143/12., 152/14., 94/16., 29/17.

Sudska praksa:

1. Portal sudske prakse SupraNova, aplikacijski sustav namijenjen za korištenje sudovima

2. Portal www.iusinfo.hr

3. Sudska praksa Europskog suda za ljudska prava, dostupno na https://hudoc.echr.coe.int 


\section{Željka Zrilić Ježek*}

Summary

\section{EXPERTISE IN ADMINISTRATIVE DISPUTE}

The purpose of the treatment of this topic is to provide an overview of the expertise procedure in administrative dispute, to showcase the rules under which said expertise is conducted, and to indicate certain specificities in comparison to civil proceedings. Some aspects of expertise are laid down, as well as the treatment of the conducted expertise in administrative proceedings, the assignment of the task to the expert according to the relevant material regulation governing a particular administrative area, and the assessment of the findings and the opinions of court experts. The purpose of the paper is to provide answers or at least give an indication of the solutions for controversial situations that arise with regard to expertise procedures, with an account of the relevant case-law.

Keywords: expert; expertise; expert finding and opinion; administrative dispute.

\section{Zussamenfassung}

\section{BEGUTACHTUNG IN VERWALTUNGSSTREITIGKEITEN}

Ziel dieses Beitrags ist, die Übersicht über die Begutachtung in Verwaltungsstreitigkeiten zu geben, sowie auch die Regeln deren Durchführung darzustellen und auf ihre Besonderheiten bezüglich des Zivilverfahrens hinzuweisen. Man stellt manche Aspekte der Begutachtung, das Verhältnis gegenüber der durchgeführten Begutachtung im Verwaltungsverfahren, die Bestimmung der Aufgaben von Sachverständigen gemäß den maßgeblichen materiellen Vorschriften, welche das entsprechende Verwaltungsbereich regulieren, und die Bewertung von Sachverständigengutachten dar. Ziel des Beitrags ist, die Lösungen für umstrittene Situationen bei der Begutachtung anzubieten, wobei die relevante Rechtsprechung dargestellt wird.

Schlüsselwörter: Sachverständige; Begutachtung; Sachverständigengutachten; Verwaltungsstreitigkeit.

* Željka Zrilić Ježek, judge, Administrative Court in Zagreb; zeljka.zrilicjezek@uszg.pravosudje. hr. 
Riassunto

\section{LA PERIZIA NEL CONTENZIOSO AMMINISTRATIVO}

Lo scopo dell'analisi di questo tema è volto ad offrire una rassegna delle perizie nel contenzioso amministrativo, ad illustrare le regole in forza delle quali esse vengono espletate ed a porre in rilievo le particolarità rispetto al contenzioso civile. Si evidenziano alcuni aspetti delle operazioni peritali; il rapporto rispetto all'effettuata perizia nel procedimento amministrativo; la determinazione dell'oggetto della perizia ai sensi della normativa applicabile, che regola un determinato ambito amministrativo e la valutazione delle perizie e dei pareri peritali. Lo scopo del lavoro è quello di offrire delle risposte o perlomeno dare dei suggerimenti per risolvere le situazioni dubbie che si manifestino nelle operazioni peritali e ciò passando in rassegna la giurisprudenza.

Parole chiave: perito; perizia; relazione e parere peritale; contenzioso amministrativo. 
